\title{
Cost-effectiveness analysis of antiemetics therapy in breast cancer patients with moderate emetogenic chemotherapy in Prof. Dr. Margono Soekarjo Hospital, Indonesia
}

\author{
Ida Dzikriyani, Didik Setiawan* \\ Faculty of Pharmacy. Universitas Muhammadiyah Purwokerto \\ Kampus I Dukuhwaluh Gedung $O$, \\ Jl. Raya Dukuhwaluh, Kembaran, Banyumas, Central Java, Indonesia
}

\begin{abstract}
Chemotherapy-induced nausea and vomiting (CINV) significantly reduce the life quality of cancer patients. A 5-HT3 receptor antagonist, corticosteroid, and H2-blocker have been used to control moderate nausea and vomit in cancer patients. The exploration of the cost-effectiveness of several antiemetic combinations in breast cancer patients in Prof. Dr. Margono Soekardjo Hospital, Purwokerto, Indonesia was the aim of this research. Seventy-four Breast cancer patients who have prescribed moderate-emetogenic chemotherapy during the year 2017-1019 were included in this research. There were fifteen patients treated with the combination of ondansetron and dexamethasone (OD). Fourteen patients were treated with the combination of ondansetron and ranitidine (OR). Thirtyfive patients were treated using ondansetron, dexamethasone, and ranitidine (ODR) combination. The effectiveness was represented by the absence of acute nausea and vomiting after receiving chemotherapy. The ODR combinations showed the highest effectivity on diminishing nausea and vomiting among breast cancer patients $(0.400)$, followed by the OD combination $(0.267)$ and the OR combination (0.214). However, the ODR combination generates the highest cost (4.6 million rupiahs) compared to other antiemetics combinations. Compared to the combination of ondansetron and dexamethasone, the combination of ODR provides higher ICER (ICER of 13 Million Rupiahs per case prevented) than the combination of OR (ICER of 8.5 million Rupiahs per case prevented). In conclusion, the combination of ondansetron, dexamethasone, and ranitidine generates the highest cost. It also provides the highest effectiveness in preventing nausea and vomiting.
\end{abstract}

Keywords: A cost-effectiveness analysis, breast cancer, ondansetron, dexamethasone, ranitidine

\footnotetext{
*Corresponding author:

Didik Setiawan

Faculty of Pharmacy, Universitas Muhammadiyah Purwokerto

Kampus I Dukuhwaluh Gedung O,

J1. Raya Dukuhwaluh, Kembaran, Banyumas, Central Java, Indonesia

Email: d.didiksetiawan@gmail.com
} 


\section{INTRODUCTION}

Breast cancer is one of the leading health problems for women in the world. In 2018, breast cancer prevalence and incidence became the highest case among Indonesian women. It stated that there were about 58.256 new cases of breast cancer diagnosed in women (Ferlay et al., 2018; Jemal et al., 2011). Chemotherapy is one of the effective treatments in breast cancer management. It potentially decreases tumor size by about $50 \%$, a $70 \%$ of patients who received chemotherapy experienced a decrease in cancer stage (Diaby et al., 2015).

Although chemotherapy provides substantial-effectiveness among cancer patients, the side effects, particularly nausea and vomiting, of chemotherapy also affect patient adherence and quality of life (Diener, 1998; Engstrom et al., 1999; Hesketh, 2008). Chemotherapy-induced nausea and vomiting (CINV) are one of the most common side effects experienced by cancer patients who received chemotherapy. There were $70-80 \%$ of cancer patients who experience nausea and vomiting due to chemotherapy will delay or refuse further cycles of chemotherapy. It reduces the patient's compliance and quality of life (Greimel et al., 2009). Therefore, the addition of antiemetics for patients who received chemotherapy is an essential part of breast cancer therapy, particularly in preventing nausea and vomiting and improve the patient's quality of life (Hesketh, 2008). Since CINV potentially extends the length of treatment, the treatment cost for cancer patients is sometimes substantially increased (Schädlich et al., 2013).

Several medicines have been used in practice and showed various effects on preventing nausea and vomiting (Navari and Aapro, 2016; Shankar et al., 2015). The sole use of 5-HT3 receptor antagonists prevents vomiting incidents for about 50\% to $70 \%$ among cancer patients (Navari, 2015). Corticosteroids are recommended in combination with 5-HT3 antagonists for patients who received moderate emetogenic chemotherapy agents (Perez, 1998). In addition, intravenous dexamethasone has been used to prevent nausea and vomiting caused by chemotherapy (Diener, 1998). Since it has a long half-life in the body, it can also provide long protection for nausea and vomiting.

The use of antiemetics in both and the combination could generate various effectiveness and cost in preventing nausea and vomiting. Therefore, cost-effectiveness analysis is required to explore the cost ratio and its effectivity on many antiemetic combinations.

\section{METHOD}

This cost-effectiveness analysis was done by collecting observational cohort data, in both clinical and economic analysis. The participants were the breast cancer patients who were treated at Prof. Dr. Margono Soekardjo Hospital, Purwokerto, Indonesia. The data was taken from the year 2017 to 2019. The patients were females who were older than 18 years old. They received initial moderateemetogenic chemotherapy and antiemetics 30 minutes before receiving chemotherapy. The exclusion criteria were pregnant patients who experienced morning sickness, patients who refused to participate in this study. According to various guidelines (Hesketh, 2008), combination chemotherapy series were considered moderate emetogenic chemotherapy. It includes Doxorubicin $50 \mathrm{mg} / \mathrm{m} 2$ i.v. and Cyclophosphamide $600 \mathrm{mg} / \mathrm{m} 2$ (AC regiment). Doxorubicin $60 \mathrm{mg} / \mathrm{m} 2$ i.v.. Paclitaxel $175 \mathrm{mg} / \mathrm{m} 2$ i.v.. Cyclophosphamide $600 \mathrm{mg} / \mathrm{m} 2$ (ATC regiment). Cyclophosphamide $500 \mathrm{mg} / \mathrm{m} 2$ i.v.. Doxorubicin 50 $\mathrm{mg} / \mathrm{m} 2$ i.v.. and Fluorouracil $500 \mathrm{mg} / \mathrm{m} 2$ i.v. (CAF regiment). Cyclophosphamide $600 \mathrm{mg} / \mathrm{m} 2$ i.v.. Methotrexate $40 \mathrm{mg} / \mathrm{m} 2$ i.v. and Fluorouracil $600 \mathrm{mg} / \mathrm{m} 2$ i.v. (CMF regiment). and Cyclophosphamide $75 \mathrm{mg} / \mathrm{m} 2$ i.v. Epirubicin $100 \mathrm{mg} / \mathrm{m} 2$ i.v. Fluorouracil $500 \mathrm{mg} / \mathrm{m} 2$ i.v. (CEF/FEC regiment). This study has been approved by the ethical committee (KEPK/UMP/22/I/2020).

Patients were classified according to the antiemetics that they received during chemotherapy: ondansetron and dexamethasone (OD) group, ondansetron and ranitidine (OR) group, ondansetron, dexamethasone, and ranitidine (ODR) combination. The information on the type of antiemetics and chemotherapy was collected from medical records. The comparator of this study is the OD group. The researcher took the recommendations from several guidelines such as the Multinational Association of Supportive Care in Cancer (MASCC), The American Society of Clinical Oncology (ASCO), The 
National Comprehensive Cancer Network (NCCN), and the European Society for Medical Oncology (ESMO) (Hesketh, 2008).

In this study, a societal perspective is implemented (Assessment, 2017). In addition, the calculation includes all expenses associated with the patient's treatment and illness. The data considered the direct medical cost, direct non-medical cost, and indirect cost. The direct medical cost consists of administration, laboratory, treatment costs (professional fee and radiotherapy), and medicine (chemotherapy and non-chemotherapy). The hospital billing became the main bill to collect the costs. The direct non-medical costs cover all expenses during treatment periods include transportation, parking, accommodation, and food. Finally, it was indirect costs. Consideration of productivity loss due to the illness and the treatment became the calculation of indirect cost. The productivity loss was calculated based on the patients' daily income and multiplied by the number of the hospitalization. It also included the possibility of the absence from work due to their illness. Both direct non-medical cost and indirect cost were collected by interviewing directly to the patients.

The absence of nausea or vomiting on the patients as the result of chemotherapy up to 24 hours after chemotherapy was considered the effectivity of antiemetics. These clinical outcomes were presented as nausea only, vomiting only, and patients who experienced both side effects. The researcher uses the medical record to collect all of the clinical data.

This research used A Chi-Square test to evaluate the differences in patients' characteristics include age, residence, educational background, occupation, types of health insurance, cancer stages, body mass index (BMI), and chemotherapy regimens. The differences in clinical outcomes were also analyzed using Chi-Square. The differences in cost among groups were analyzed using the Kruskal Wallis test. Finally, the research reached the main result of the cost-effectiveness analysis. The Incremental Cost-Effectiveness Ratio (ICER), as stated in (Setiawan et al., 2016) was calculated by dividing the incremental cost and the incremental effectiveness.

\section{RESULT AND DISCUSSION}

Initially, 556 patients were identified according to their diagnosis (C50.9). The confirmation process from medical records resulted 482 breast cancer patients were excluded due to various reasons (Figure $1)$.

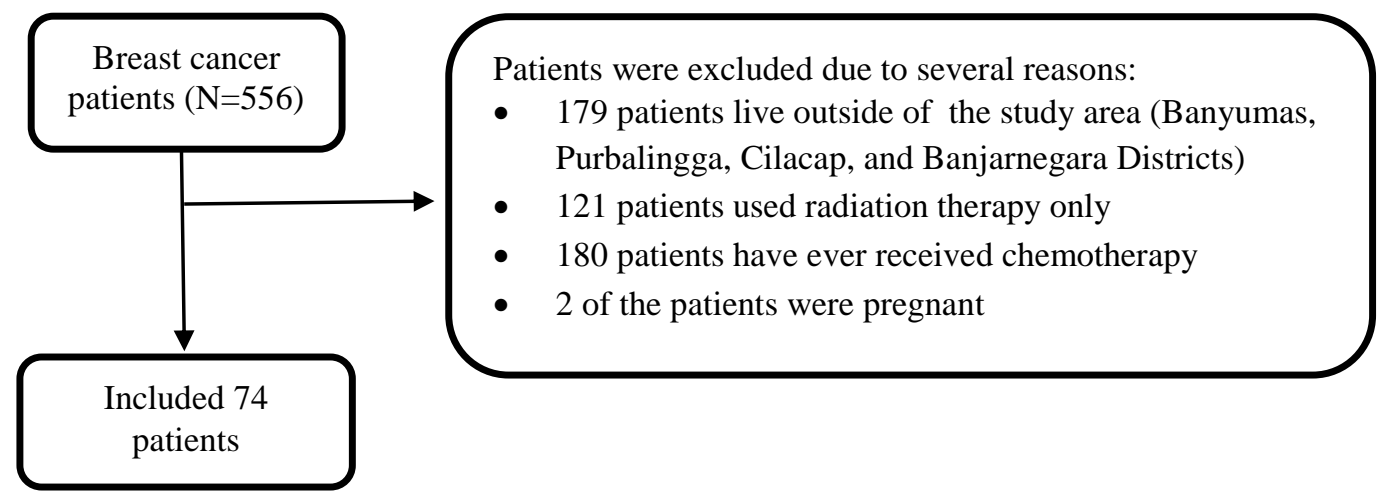

Figure 1. Breast cancer patient flow in this study 
Table 1. Breast cancer patient characteristics

\begin{tabular}{|c|c|c|c|c|c|}
\hline Patient characteristics & OD $(n=15)$ & OR $(n=14)$ & $\operatorname{ODR}(n=45)$ & Total $(n=74)$ & P-value \\
\hline \multicolumn{6}{|l|}{ Age (\%) } \\
\hline 20-29 years old & $0(0.0)$ & $0(0.0)$ & $1(2.2)$ & $1(1.4)$ & \multirow{5}{*}{0.554} \\
\hline 30-39 years old & $2(13.3)$ & $0(0.0)$ & $7(15.6)$ & $9(12.1)$ & \\
\hline 40-49 years old & $5(33.3)$ & $7(50.0)$ & $15(33.3)$ & $27(36.4)$ & \\
\hline $50-59$ years old & $4(26.7)$ & $5(35.7)$ & $18(40.0)$ & $27(36.4)$ & \\
\hline$>60$ years old & $4(26.7)$ & $2(14.3)$ & $4(8.9)$ & $10(13.5)$ & \\
\hline \multicolumn{6}{|l|}{ Body Mass Index (BMI) } \\
\hline$<18$ & $0(0.0)$ & & $3(6.7)$ & $3(4 \%)$ & \multirow{4}{*}{0.503} \\
\hline $\begin{array}{l}18.5-24.9 \\
25-209\end{array}$ & $9(60.0)$ & $8(57.1)$ & $27(60.0)$ & $44(59.5 \%)$ & \\
\hline $\begin{array}{l}25-29.9 \\
>30\end{array}$ & $4(26.7)$ & $6(42.9)$ & $10(22.2)$ & $20(27 \%)$ & \\
\hline$>30$ & $2(13.3)$ & $0(0.0)$ & $5(11.1)$ & $7(9.5 \%)$ & \\
\hline \multicolumn{6}{|l|}{ Residence (\%) } \\
\hline Banyumas district & $9(60.0)$ & $9(64.3)$ & $22(48.9)$ & $40(54.0)$ & \multirow{4}{*}{0.381} \\
\hline Purbalingga district & $1(6.7)$ & $0(0.0)$ & $5(11.1)$ & $6(8.1)$ & \\
\hline Cilacap district & $2(13.3)$ & $0(0.0)$ & $9(20.0)$ & $11(14.9)$ & \\
\hline Banjarnegara district & $3(20.0)$ & $5(35.7)$ & $9(20.0)$ & $17(23.0)$ & \\
\hline \multicolumn{6}{|l|}{ Education } \\
\hline Uneducated & $1(6.7)$ & $0(0.0)$ & $0(0.0)$ & $1(1.4)$ & \multirow{6}{*}{0.219} \\
\hline Elementary school & $8(53.3)$ & $10(71.4)$ & $20(44.4)$ & $38(51.4)$ & \\
\hline Junior high school & $3(20.0)$ & $0(0.0)$ & $4(8.9)$ & $7(9.5)$ & \\
\hline Senior high school & $2(13.3)$ & $4(26.6)$ & $14(31.1)$ & $20(27.0)$ & \\
\hline Diploma & $0(0.0)$ & $0(0.0)$ & $3(6.7)$ & $3(4.0)$ & \\
\hline Bachelor & $1(6.7)$ & $0(0.0)$ & $4(8.9)$ & $5(6.7)$ & \\
\hline \multicolumn{6}{|l|}{ Occupation } \\
\hline Does not have a job & $2(13.3)$ & $2(14.3)$ & $3(6.7)$ & $7(9.5)$ & \multirow{7}{*}{0.426} \\
\hline Housewife & $10(66.7)$ & $7(50.0)$ & $21(46.7)$ & $38(51.4)$ & \\
\hline Private sector & $1(6.7)$ & $0(0.0)$ & $5(11.1)$ & $6(8.1)$ & \\
\hline Employee & $0(0.0)$ & $1(7.1)$ & $4(8.9)$ & $5(6.7)$ & \\
\hline Laborer & $2(13.3)$ & $1(7.1)$ & $3(6.7)$ & $6(8.1)$ & \\
\hline Farmer & $0(0.0)$ & $0(0.0)$ & $5(11.1)$ & $5(6.7)$ & \\
\hline Civil servant & $0(0.0)$ & $3(21.5)$ & $4(8.9)$ & $7(9.5)$ & \\
\hline \multicolumn{6}{|l|}{ Health Insurance } \\
\hline BPJS PBI & $4(26.6)$ & $5(35.7)$ & $14(31.1)$ & $23(31.0)$ & \multirow{5}{*}{0.204} \\
\hline BPJS non PBI & $9(60.0)$ & $7(50.0)$ & $30(66.7)$ & $46(62.2)$ & \\
\hline JAMKESDA & $0(0.0)$ & $0(0.0)$ & $1(2.2)$ & $1(1.4)$ & \\
\hline Non-Insurance & $1(6.7)$ & $2(14.3)$ & $0(0.0)$ & $3(4.0)$ & \\
\hline YPP & $1(6.7)$ & $0(0.0)$ & $0(0.0)$ & $1(1.4)$ & \\
\hline \multicolumn{6}{|l|}{ Cancer Stages } \\
\hline 0 & $0(0.0)$ & $0(0.0)$ & $0(0.0)$ & $0(0.0)$ & \multirow{5}{*}{0.529} \\
\hline I & $0(0.0)$ & $1(7.1)$ & $6(13.3)$ & $7(9.5)$ & \\
\hline II & $3(20.0)$ & $4(26.6)$ & $11(24.4)$ & $18(24.3)$ & \\
\hline III & $7(46.7)$ & $7(50.0)$ & $22(48.9)$ & $36(48.6)$ & \\
\hline IV & $5(33.3)$ & $2(14.3)$ & $6(13.3)$ & $13(17.6)$ & \\
\hline \multicolumn{6}{|l|}{ Chemotherapy Regiment } \\
\hline FAC & $1(6.7)$ & $0(0.0)$ & $9(20.0)$ & $10(13.5)$ & \multirow{4}{*}{0.197} \\
\hline $\mathrm{AC}$ & $8(53.3)$ & $4(26.6)$ & $11(24.4)$ & $23(31.1)$ & \\
\hline ETC & $1(6.7)$ & $2(14.3)$ & $3(6.7)$ & $6(8.1)$ & \\
\hline ET & $5(33.3)$ & $8(57.1)$ & $22(48.9)$ & $35(47.3)$ & \\
\hline
\end{tabular}

OD: ondansetron and dexamethasone; OR: ondansetron and ranitidine; ODR: ondansetron. dexamethasone and ranitidine; BPJS PBI: Badan Pengelola Jaminan Sosial Penerima Bantuan Iuran; BPJS non PBI: Badan Pengelola Jaminan Sosial non Penerima Bantuan Iuran; Jamkesda: Jaminan Kesehatan Daerah; YPP: Yayasan Kesehatan Pertamina; FAC: Fluorouracil 500 
$\mathrm{mg} / \mathrm{m} 2$ i.v.. Doxorubicin $50 \mathrm{mg} / \mathrm{m} 2$ i.v.. and Cyclophosphamide $500 \mathrm{mg} / \mathrm{m} 2$ i.v.; AC: Doxorubicin $50 \mathrm{mg} / \mathrm{m} 2$ i.v. and Cyclophosphamide $600 \mathrm{mg} / \mathrm{m} 2$; ETC: Epirubicine $100 \mathrm{mg} / \mathrm{m} 2$ i.v.. Paclitaxel $175 \mathrm{mg} / \mathrm{m} 2$ i.v.. Cyclophosphamide 75 mg/m2 i.v.; ET: Epirubicine $100 \mathrm{mg} / \mathrm{m} 2$ i.v.. Paclitaxel $175 \mathrm{mg} / \mathrm{m} 2$ i.v.

Seventy-four breast cancer patients were included in the final analysis. Most of the age patients were in the range of 40 to 60 years old. They also have an average Body Mass Index (BMI of 18.5 to 24.9). The socioeconomic factor of the patients showed that most of them lived in the Banyumas district (54.0\%), finished elementary school (51.4\%), were a housewife (51.4\%) and used BPJS nonPBI scheme for their health insurance.

The clinical background of the patients (Table 1) showed that most of them were in the breast cancer stage III (48.6\%). They received the combination of Epirubicin $100 \mathrm{mg} / \mathrm{m}^{2}$ i.v. and Paclitaxel $175 \mathrm{mg} / \mathrm{m}^{2}$ i.v. regiments $(47.3 \%)$. Overall, there are no significant differences in both socioeconomic and clinical characteristics among anti-emetics groups (all $p$ values are higher than 0.05 ).

Table 2. Comparison of the effectiveness of the antiemetic regimen by looking at the incidence of nausea and vomiting

\begin{tabular}{lllll}
\hline Side Effects & OD $(\mathbf{n = 1 5})$ & OR $(\mathbf{n = 1 4})$ & ODR $(\mathbf{n = 4 5})$ & $\boldsymbol{p}$-value \\
\hline Nausea $(\%)$ & $8(53.3)$ & $11(78.6)$ & $23(46.7)$ & 0.112 \\
Vomiting (\%) & $5(33.3)$ & $8(57.1)$ & $11(24.4)$ & 0.074 \\
Nausea and Vomiting (\%) & $11(73.3)$ & $11(78.6)$ & $27(60.0)$ & 0.355 \\
No nausea and no vomiting (\%) & $4(26.7)$ & $3(21.4)$ & $18(40.0)$ & 0.355 \\
\hline $\begin{array}{l}\text { OD: ondansetron and dexamethasone; } \\
\text { dexamethasone and ranitidine }\end{array}$ & OR: ondansetron and ranitidine; ODR: ondansetron,
\end{tabular}

The incidence of nausea and or vomiting solely among patients who received OD and OR combination is noticeably higher than the patient who was treated using ODR combination. Breast cancer patients in the OR group experienced the highest nausea (78.6\%), vomiting $(57.1 \%)$, and the combination of both nausea and vomiting (78.6\%). However, the differences in the side effects experienced are not statistically significant (all $p$ values are higher than 0.05 ) (Table 2).

Table 3. The cost of illness (in 1.000 rupiahs) of breast cancer patients in Prof. Dr. Margono Hospital

\begin{tabular}{|c|c|c|c|c|c|c|}
\hline $\begin{array}{l}\text { Type of cost } \\
\text { (x } 1.000 \text { rupiahs) }\end{array}$ & $\begin{array}{l}\text { OD } \\
\text { Mean }\end{array}$ & SD & $\begin{array}{l}\text { OR } \\
\text { Mean } \\
\end{array}$ & SD & $\begin{array}{l}\text { ODR } \\
\text { Mean } \\
\end{array}$ & SD \\
\hline \multicolumn{7}{|l|}{ Direct Medical Cost } \\
\hline Administration & 5.2 & 1.4 & 5.0 & 0.0 & 4.9 & 3.0 \\
\hline Laboratory & 111.5 & 9.8 & 108.6 & 13.7 & 120.5 & 76.2 \\
\hline Treatment & 1.594 .3 & 767.6 & 1.874 .5 & $1,784.9$ & 1.458 .8 & 841.9 \\
\hline Medication & 1.020 .5 & 371.5 & 675.9 & 0.0 & 2.609 .6 & 605.7 \\
\hline \multicolumn{7}{|c|}{ Direct non-Medical Cost } \\
\hline Transportation & 53.1 & 28.8 & 53.93 & 30.7 & 42.05 & 21.4 \\
\hline Parking & 2.8 & 2.1 & 3.71 & 1.5 & 2.6 & 2.1 \\
\hline Food & 16.0 & 10.3 & 15.0 & 11.6 & 16.4 & 11.9 \\
\hline Accommodation & 6.7 & 25.8 & 1.5 & 3.7 & 230.5 & $1,522.5$ \\
\hline \multicolumn{7}{|l|}{ Indirect Cost } \\
\hline Productivity loss & 15.9 & 38.1 & 149.0 & 301.1 & 75.5 & 122.1 \\
\hline Total & 2.825 .9 & 816.9 & 2.374 .5 & 504.5 & 4.557 .9 & $1,792.8$ \\
\hline
\end{tabular}

During their hospitalization, breast cancer patients who were included in OD (Rp.1.6 Million) and OR (Rp.1.9 Million) groups mostly spent their resources on treatment such as fees for doctors and 
nurses or radiotherapy, while the patient in the ODR group mostly spent their resources for the medication (Rp.2.6 Million) (Table 3). Concerning the direct cost that had been spent for non-medical items, patients in OD (Rp.53 Thousand) and OR (Rp.54 Thousand) groups spent most of the resources for the transportation to the hospital. In contrast, patients in the ODR group spent most of the resources for accommodation (RP.230.1 thousand). In this study, patients in OR groups experienced the greatest loss in their productivity (Rp.149 Thousand) due to their illness and or treatments.

Table 4. Cost-effectiveness analysis of antiemetic therapy in breast cancer patients

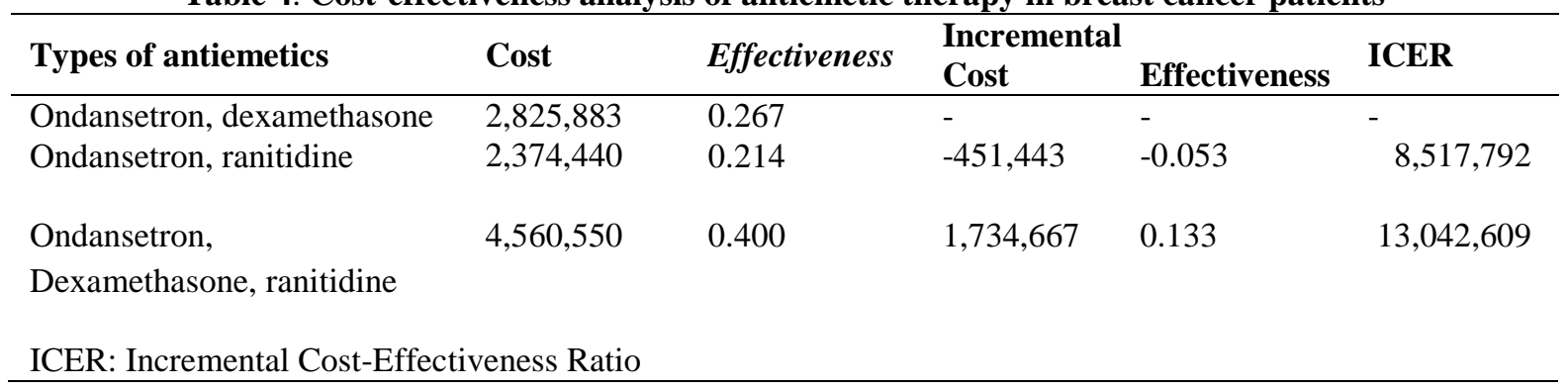

Compared to the antiemetic OD combination, the cost of treatment of OR combination was lower (-Rp.451 Thousand). However, it prevented less nausea and vomiting $(-0.053)$ in breast cancer patients (Table 4). On the other hand, the ODR combination increases the prevention of nausea and vomiting (0.133) among breast cancer patients, but the consequence is that the cost of treatment was also increased (Rp.1.7 Million). Although both alternatives, OR and ODR combination, generate positive ICER, the location of both alternatives is different. The OR combination is located at the third quadrant of the Cost-Effectiveness Plane (CEP). The ODR combination is located at the first quadrant with the ICER of Rp13 Million for each nausea and vomiting case prevented.

\section{Discussion}

In terms of clinical outcome in Indonesia, this study is the first economic evaluation providing evidence that compared the recommended standard of care for chemotherapy-induced nausea and vomiting. The combination of ondansetron, dexamethasone, and ranitidine (ODR) provides higher prevention of nausea and vomiting-induced chemotherapy and increases the cost of treatments for breast cancer patients in Indonesia. However, this combination is clinically acceptable since it is also recommended by some guidelines, such as the National Comprehensive Cancer Network (NCCN). The addition of ranitidine in the existing regiment will increase the total cost of treatment. This finding is similar to several other studies, although the types of chemotherapy used are different (Pradermdee et al., 2006). The increase in the ODR combination cost was not significantly different. However, this increase must be carefully considered since the treatment cost for any diseases in Indonesia is limited by the standard price, namely Indonesian Case-Based Group (INA-CBGs) (Indonesia, 2013).

From the clinical perspective, the ODR combination should be preferred as the main recommendation for patients who will potentially gain the highest benefit such as the age of 40 to 60 years old, having normal BMI (18.5-24.9), in stage III of breast cancer, and receiving ET chemotherapy combination. The consideration is essential since chemotherapy-induced nausea and vomiting is one of the main issues that increase chemotherapy failure. Patients generally refuse to continue the therapy plan if this side effect is substantially reducing their life quality. The mechanism of this side effect is that chemotherapy drugs generally increase the secretion of substance $\mathrm{P}$ from neurons in the nervous systems and then binds to neurokinin-1 (NK1) receptors to induce vomiting (Muñoz and Coveñas, 2019). Based on chemotherapy-induced nausea and vomiting, there is a considerably new antiemetic therapy, Aprepitant - a selective neurokinin-1 receptor antagonist, that has been used widely to prevent chemotherapy-induced nausea and vomiting. It showed that the 
combination uses Aprepitant was also cost-effective for this purpose (Kang et al., 2018). However, this new drug has not been registered for the Indonesian market.

One of the advantages of this study is that this study used the clinical outcome of chemotherapyinduced nausea and vomiting. Nausea and vomiting are important issues since it has been known as the main obstacles of the successfulness of chemotherapy. This study will be beneficial for communication with the clinician since their main concern is mostly clinical benefit for patients. However, since health economic evaluation is generally used to encourage the decision-maker, who are usually not only consider clinical outcome but also economic outcome, this study provides less comprehensive recommendation since the ICER could not be compared with any willingness to pay which uses utility or Quality Adjusted Life Years (QALYs) as the denominator in the formula.

We understand that this study has limited samples. The sample was only from one hospital in Indonesia. This limitation could potentially reduce the applicability of the results. However, most of the hospitals in Indonesia that take care of cancer patients are of the same type as Prof Dr. Margono Public Hospital, which is a type B accredited hospital. There is a very limited type $\mathrm{C}$ hospital that has the capacity and capability on treating cancer patients in Indonesia and therefore, this study's results can be, at least, implemented in many other type B hospitals in Indonesia. In addition, several factors could influence the value of treatment cost such as the class of hospitalization, types of chemotherapy used, and also patient comorbidities. Therefore, more data is required to perform the subgroup analysis to evaluate the impact of those confounding factors on the treatment cost.

Another limitation of this study is that nausea and vomiting were collected from medical records. Chemotherapy-induced nausea and vomiting information should be confirmed using various checklists such as the Naranjo checklist or WHO-UMC criteria (Belhekar et al., 2014;García-Cortés et al., 2008). This confirmation process can theoretically increase the validity of the relation between chemotherapy and the side effect of nausea and vomiting experienced by the patients. Therefore, further research is required to improve our findings on the cost-effectiveness analysis of antiemetic therapy to prevent chemotherapy-induced nausea and vomiting in cancer patients by including more patients and more hospitals. The next study also has to consider QALYs as the outcome of the therapy.

\section{CONCLUSION}

In conclusion, our study showed that although both combinations (OR and ODR) are considerably cost-effective strategies for reducing nausea-related chemotherapy on breast cancer patients, the combination of ondansetron, dexamethasone, and ranitidine is considered the most favorable option since it offers more benefits and an acceptable additional cost.

\section{REFERENCES}

Assessment, I. H. T. (2017). Health Technology Assessment (HTA) Guideline.

Belhekar, M. N., Taur, S. R., \& Munshi, R. P. (2014). A study of agreement between the Naranjo algorithm and WHO-UMC criteria for causality assessment of adverse drug reactions. Indian Journal of Pharmacology, 46(1), 117-120. https://doi.org/10.4103/0253-7613.125192

Diaby, V., Tawk, R., Sanogo, V., Xiao, H., \& Montero, A. J. (2015). A review of systematic reviews of the cost-effectiveness of hormone therapy, chemotherapy, and targeted therapy for breast cancer. Breast Cancer Research and Treatment, 151(1), 27-40. https://doi.org/10.1007/s10549$\underline{015-3383-6}$

Diener, K. M. (1998). Chemotherapy-induced nausea and vomiting. Journal of Pharmaceutical Care in Pain \& Symptom Control, 6(4), 23-50. https://doi.org/10.1300/J088v06n04_03

Engstrom, C., Hernandez, I., Haywood, J., \& Lilenbaum, R. (1999). The efficacy and cost effectiveness of new antiemetic guidelines. Oncology Nursing Forum, 26((9)), 1453-1458

García-Cortés, M., Lucena, M. I., Pachkoria, K., Borraz, Y., Hidalgo, R., \& Andrade, R. J. (2008). Evaluation of naranjo adverse drug reactions probability scale in causality assessment of druginduced liver injury. Alimentary Pharmacology \& Therapeutics, 27(9), 780-789. 
https://doi.org/10.1111/j.1365-2036.2008.03655.x

Greimel, E. R., Winter, R., Kapp, K. S., \& Haas, J. (2009). Quality of life and sexual functioning after cervical cancer treatment: a long-term follow-up study. Psychooncology, 18 (5), 476-482

Hesketh, P. J. (2008). Chemotherapy-induced nausea and vomiting. New England Journal of Medicine, 358(23), 2482-2494. https://doi.org/10.1056/NEJMra0706547

Indonesia, M. K. R. (2013). Standar tarif pelayanan kesehatan pada fasilitas kesehatan tingkat pertama dan fasilitas kesehatan tingkat lanjutan dalam penyelenggarakan program jaminan kesehatan

J, Ferlay., M, Ervik., F, Lam., M, Colombet., L, Mery., M, Piñeros., A, Znaor., \& B, Soerjomataram. I. (2018). Cancer Today (powered by Globocan 2018)

Jemal, A., Bray, F., Center, M. M., Ferlay, J., Ward, E., \& Forman, D. (2011). Global cancer statistics. CA: A Cancer Journal for Clinicians, 61(2), 69-90. https://doi.org/10.3322/caac.20107

Kang, H. J., Loftus, S., DiCristina, C., Green, S., Pong, A., \& Zwaan, C. M. (2018). Aprepitant for the prevention of chemotherapy-induced nausea and vomiting in paediatric subjects: An analysis by age group. Pediatric Blood \& Cancer, 65(10), e27273. https://doi.org/10.1002/pbc.27273

Muñoz, M., \& Coveñas, R. (2019). Glioma and Neurokinin-1 Receptor Antagonists: A New Therapeutic Approach. Anti-Cancer Agents in Medicinal Chemistry, 19(1), 92-100. https://doi.org/10.2174/1871520618666180420165401

Navari, R. M. (2015). 5-HT3 receptors as important mediators of nausea and vomiting due to chemotherapy. Biochimica et Biophysica Acta (BBA) - Biomembranes, 1848(10), 2738-2746. https://doi.org/10.1016/j.bbamem.2015.03.020

Navari, R. M., \& Aapro, M. (2016). Antiemetic prophylaxis for chemotherapy-induced nausea and vomiting. New England Journal of Medicine, 374(14), 1356-1367. https://doi.org/10.1056/NEJMra1515442

Perez, E. A. (1998). Use of dexamethasone with 5-HT3-receptor antagonists for chemotherapyinduced nausea and vomiting. The Cancer Journal from Scientific American, 4(2), 72-77

Pradermdee, P., Manusirivithaya, S., Tangjitgamol, S., Thavaramara, T., \& Sukwattana, P. (2006). Antiemetic effect of ondansetron and dexamethasone in gynecologic malignant patients receiving chemotherapy. Journal of the Medical Association of Thailand = Chotmaihet Thangphaet, 89 Suppl 4, S29-36

Schädlich, P. K., Klussmann, Chen, \& Rémy. (2013). Annual cost of hospitalization, inpatient rehabilitation, and sick leave for head and neck cancers in Germany. ClinicoEconomics and Outcomes Research, 203. https://doi.org/10.2147/CEOR.S43393

Setiawan, D., Dolk, F. C., Suwantika, A. A., Westra, T. A., WIlschut, J. C., \& Postma, M. J. (2016). Cost-utility analysis of human papillomavirus vaccination and cervical screening on cervical cancer patient in Indonesia. Value in Health Regional Issues, 9, 84-92. https://doi.org/10.1016/j.vhri.2015.10.010

Shankar, A., Roy, S., Malik, A., Julka, P., \& Rath, G. (2015). Prevention of chemotherapy-induced nausea and vomiting in cancer patients. Asian Pacific Journal of Cancer Prevention, 16(15), 6207-6213. https://doi.org/10.7314/APJCP.2015.16.15.6207 